\title{
Household characteristics and demand for private tutoring in Indonesia
}

\author{
W. Wahyuni \& H. Susanti \\ Department of Economics, Faculty of Economics and Business, Universitas Indonesia, Depok, Indonesia
}

\begin{abstract}
This research aims to identify the effects of household characteristics in household demand for private tutoring function by using the Tobit model. The household characteristics are represented by a number of variables such as household income rate, parents' educational level, and number of family members. The results show that the demand for private tutoring increases along with the higher level of household income, children's education level, household location in urban areas and the lower number of family members. The impact of the fathers' educational level on household demand for private tutoring is higher than that of the mothers' educational level.
\end{abstract}

\section{INTRODUCTION}

Indonesian parents nowadays are dealing with anxiety about their children's academic achievement as an impact of the educational system applied in Indonesia. In order to maintain the national educational system, the Indonesian government, through the Government Regulation Number 19 Year 2005, stipulates a minimum standard of academic competence as a requirement for promotion to a higher grade, graduation and application to a higher educational level. More examinations arranged both by the government and schools, in order to measure competence and categorise students according to their academic competence level, may lead to competition among students in terms of academic achievement. Moreover, they also need to compete in order to get into favourite universities, as one of the preparations needed to enhance their competence in the labour market competition. This condition motivates both parents and children to seek more lessons, in addition to the ones they get from their schools. It indicates an increase of the households' demand for education (Bray \& Kwok, 2003).

The increase of such households' demand for education is used as an opportunity to develop private tutoring businesses, either by schools, individuals or private tutoring agencies. This is in line with Takayama et al. (2013) who explain that the high level of academic competition in South Korea boosts the growth of private tutoring industries. On the other hand, Finland, a country that runs an educational system without any examinations to determine promotion to a higher grade and higher educational level, shows that private tutoring is not necessarily needed. Private tutoring is a supplementary instruction given after or outside of school hours, using a method where the tutors deliver materials in more innovative and flexible ways, and the parents must pay for their services (Dang \& Rogers, 2008). In general, private tutoring concentrates more on students' success in school examination or admission to favourite universities (Kim \& Lee, 2010; Mori \& Baker, 2010). This sector has become a rapidly growing industry and is called 'shadow education', due to its presence that grows along with the development of the educational system applied in a country as a supplement for the lack of existing formal education (Bray et al., 2014).

The growth of private tutoring in Indonesia always increases year after year. Figure 1 shows the increasing number of agencies that provide private tutoring, commonly known as tutoring agencies. The large number of tutoring agencies indicates high household demand for 


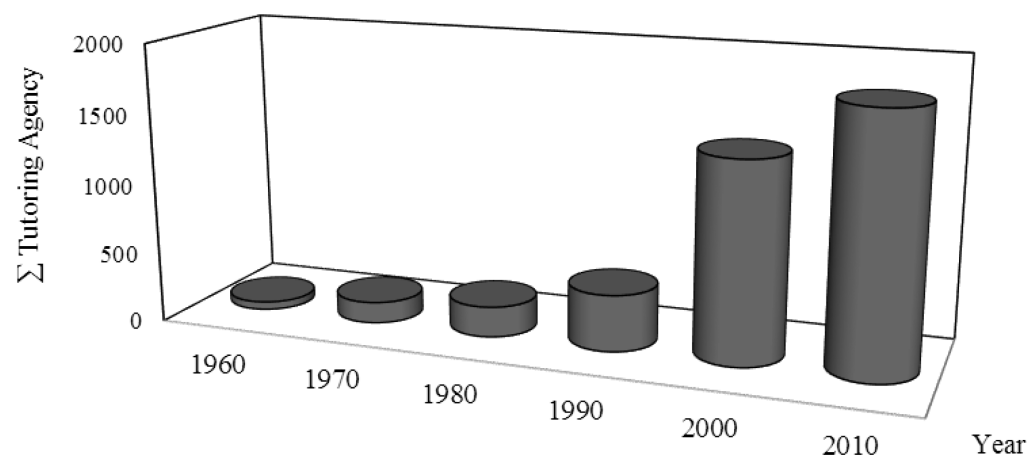

Figure 1. Growth of total tutoring agencies registered in Indonesia. Source: Ministry of Education and Culture of Republic of Indonesia.

additional instruction given after or outside school hours and is also considered a response to the inability of the existing formal educational system in accommodating household needs for education (Dang, 2007; Kim \& Lee, 2010). Data regarding the presence and activities of private tutoring, whether provided by agencies, schools or individuals in Indonesia, are generally hard to obtain. Therefore, according to Bray and Kwok (2003), in order to see the demand for private tutoring, it will be easier for us to use household data.

Several empirical studies that examined household total expenditure on education in Indonesia were conducted by Kristiansen and Praktikno (2006) and Novita (2008). So far, we have not found the specific reference for the private tutoring. Several previous empirical studies show that private tutoring is considered an essential commodity in a household (Psacharopoulos \& Papakonstantinou, 2005; Dang, 2007). In accordance to the explanation above, this study aims to identify the effects of household characteristics on household demand for private tutoring.

\section{DETERMINANT OF HOUSEHOLD DEMAND FOR PRIVATE TUTORING}

Several studies find that household demand for private tutoring is affected by household characteristics, some of which are household income rate, parents' educational level, age of the head of the household and number of family members. The higher the household income rate, the more disposable income can be spent and the more spending allocation options can be chosen by the household members. A household that has a higher preference or higher expectation on children's education is likely to spend more money taken from the income, to invest on children's education. One of the ways is to spend it on private tutoring.

Parents with higher education level commonly have a higher preference and expectation on returns for children's education in the future. This leads them to allocate more expenditure on children's private tutoring (Dang \& Rogers, 2008). Previous studies show that the effect of mothers' education on the expenditure on private tutoring in Turkey and Vietnam is more dominant than fathers' education (Tansel \& Bircan, 2006; Dang, 2007). Meanwhile, fathers' education does not significantly affect the amount of household expenditure on private tutoring in Hong Kong (Bray et al., 2014), and fathers' and mothers' education do not significantly affect the amount of household expenditure on private tutoring in Malaysia (Jelani et al., 2014).

A larger number of family members causes a decrease in household expenditure rate for private tutoring in Turkey, Vietnam and Korea (Tansel \& Bircan 2006; Kim \& Lee 2010). This happens due to the fact that households face budget constraints that should be allocated for all family members. A different result is seen in which a larger number of family members does not reduce the household expenditure on private tutoring in Hong Kong 
(Bray et al., 2014) and Malaysia (Jelani et al., 2014). As the head of a household grows older, it is assumed that there will be more experience. Moreover, at a certain age, usually a household's economic condition is becoming settled. In that case, the awareness level of the parents on the importance of children's education is becoming higher. It may lead to increasing the household expenditure on private tutoring at a decreasing rate (Dang, 2007; Tansel \& Bircan, 2006; Davies, 2004).

Corresponding to children's gender, none of the previous studies have found any discriminations of gender on household expenditure on private tutoring (Bray et al., 2014; Jelani et al., 2014; Dang, 2007). The demand for private tutoring increases along with the increase in education level and types of school. Public schools in Hong Kong positively affect the increase in household demand for private tutoring compared to private schools (Bray et al., 2014).

\section{THEORETICAL AND EMPIRICAL MODEL}

\subsection{Theoretical model}

This study utilises the basic theory of Becker and Lewis (1973), that households, in maximising their utility function, are affected by the number of children, $\mathrm{n}$, the quality of children, $\mathrm{q}$, and the consumption of a number of goods, $\mathrm{x}$, with the determined price $(P \mathrm{x})$ equal to 1 , since it is assumed that the price determined for all households is the same. In maximising their utility function, households face a budget constraint, I.

$$
\begin{gathered}
\operatorname{Max} U(n, q, x) \\
P_{x} X+n\left(p_{q} q\right)=I
\end{gathered}
$$

Furthermore, in order to analyse and explain households' decision in deciding to invest on children's education through private tutoring, Dang and Rogers (2016) developed that theory by adding the quality of children, and formal education constraint, formulated as follows:

$$
\begin{gathered}
q=e_{u}+e_{r} \\
e_{u} \leq \bar{e}_{u}
\end{gathered}
$$

The quality of children $(q)$ is the total of formal education $\left(e_{u}\right)$ and private tutoring $\left(e_{r}\right)$ which the household invests for the children. Meanwhile, $p_{q}$ is the existing price in household investment for the quality of children, which is ${ }_{q}={ }_{u}$ or ${ }_{r}$. The existing formal education is assumed to have a limited capacity in improving the quality of children according to the expectations of the household $\left(\overline{\boldsymbol{e}}_{u}\right)$. The number and quality of children, and the amount of products consumed by the household, are assumed to be non-negative ( $n \geq 0, q \geq 0$ and $y \geq 0$ ).

From the result of maximising households' utility function, which shall deal with the three constraints, and by assuming that the marginal of household utility with budget constraints $\left(\lambda_{1}\right)$ is positive, we obtain an equation described as follows:

$$
\begin{gathered}
q^{*}=f\left(I, p_{u}, p_{r}\right) \\
e_{r}^{*}=f\left(I, p_{u}, p_{r}\right) \\
E_{r}=p_{r} e_{r}^{*}=p_{r} f\left(I, p_{u}, p_{r}\right) \\
\lambda_{2}\left(\overline{\boldsymbol{e}}_{u}-e_{u}\right)=0
\end{gathered}
$$


In this case, $E r$ is household demand for private tutoring. According to the Equation 8, it is implied that the marginal of household utility on formal education constraint $\left(\lambda_{2}\right)$ is:

1. If $\lambda_{2}=0$, it is assumed that the household does not maximally consume the quality of existing formal education $\left(e_{u} \leq \overline{\boldsymbol{e}}_{u}\right)$. This occurs in households with lower demand and preference for education.

2. If $\lambda_{2}>0$, it is assumed that the household has maximally consumed all of the quality of existing formal education $\left(e_{u}=\overline{\boldsymbol{e}}_{u}\right)$. It may lead to an implication that for households with higher demand and preference for education, in order to improve the quality of their children, they do not have any other choice other than investing their expenditure on private tutoring. Since $e_{u}=\overline{\boldsymbol{e}}_{u}$, then private tutoring is the only one option to maximise household demand as a supplement for education.

\subsection{Empirical model}

According to the theoretical model and other previous empirical studies, a model was developed as follows:

$$
E_{r}=P_{r} f\left(I, P_{r}, P_{u}, Z\right)
$$

where

$E_{r}=$ household demand for private tutoring;

$I=$ household permanent income;

$P_{r}=$ price of private tutoring;

$P_{u}=$ price of formal education;

$Z=$ variable of household characteristics vector.

Therefore, the empirical model utilised in this study can be described as follows:

$$
\mathrm{Er}_{\mathrm{ij}}=\beta_{1}+\beta_{2} \mathrm{I}_{\mathrm{i}}+\beta_{3} \mathrm{Pr}_{\mathrm{ij}}+\beta_{4} \mathrm{Pu}_{\mathrm{ij}}+\beta_{5} \mathrm{Z}_{\mathrm{j}}+\varepsilon_{\mathrm{ij}}
$$

The problem in this study is that many households choose zero spending on private tutoring. Several previous studies that have a similar type of data utilise the Tobit estimation method proposed by Amemiya (1974). To cope with this simultaneously, the household total expenditure and private tutoring expenditure are estimated using Two Stage Least Squares Models (Smith \& Blundell, 1986) by using current income as the instrument variables (Liviatan, 1961).

\section{DATA DESCRIPTION AND PRIVATE TUTORING SITUATION IN INDONESIA}

This study uses secondary data from the National Socio-Economic Household Survey (SUSENAS) in 2012 (SUSENAS, 2012). The majority of households that still have children who attend school spend about $1 \%$ to $5 \%$ of their total income for private tutoring. The percentage number of richest households (quintile 5) whose spending for private tutoring is larger than the poorest household (quintile 1) is shown to be $32.51 \%$ and $15.66 \%$ respectively. The higher the level of household income, the more the households choose to spend on private tutoring (Table 1).

The average of fathers' and mothers' education level in households with positive expenditure on private tutoring is higher than households with zero expenditure on private tutoring. The average level of fathers' education for both households with positive or zero expenditure is higher than the average of mothers' education level (Figure 2). An increase in the number of family members initially increases household spending on private tutoring, up to the point when the number of family members reaches an average of four people. Then households start to reduce their spending on private tutoring (Figure 3). 
Table 1. Percentage of households that consume private tutoring according to percentage of private tutoring expenditure of total household expenditure and total household expenditure groups (\%).

\begin{tabular}{lrrrrrr}
\hline \multirow{2}{*}{$\begin{array}{l}\text { Percentage of private } \\
\text { tutoring expenditure (\%) }\end{array}$} & \multicolumn{7}{l}{ Total household expenditure groups } \\
\cline { 2 - 7 } & Quint.1 & Quint.2 & Quint.3 & Quint.4 & Quint.5 & Total \\
\hline $1-5 \%$ & 14.66 & 14.69 & 17.07 & 21.07 & 32.51 & 100.00 \\
& 91.21 & 86.98 & 80.79 & 71.56 & 69.74 & 76.83 \\
& 4.69 & 7.29 & 13.45 & 27.78 & 46.79 & 100.00 \\
& 8.79 & 13.02 & 19.21 & 28.44 & 30.26 & 23.17 \\
Total & 12.35 & 12.97 & 16.23 & 22.63 & 35.82 & 100.00 \\
& 100.00 & 100.00 & 100.00 & 100.00 & 100.00 & 100.00 \\
\hline
\end{tabular}

Source: Calculation from SUSENAS 2012.

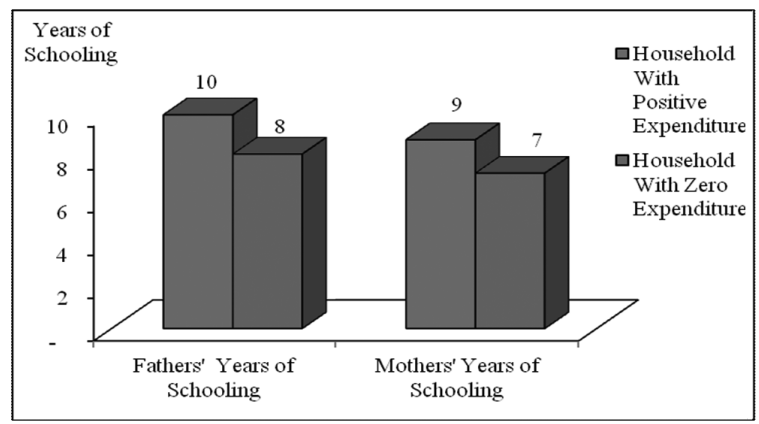

Figure 2. Average level of parents' education for households with positive expenditure and zero expenditure.
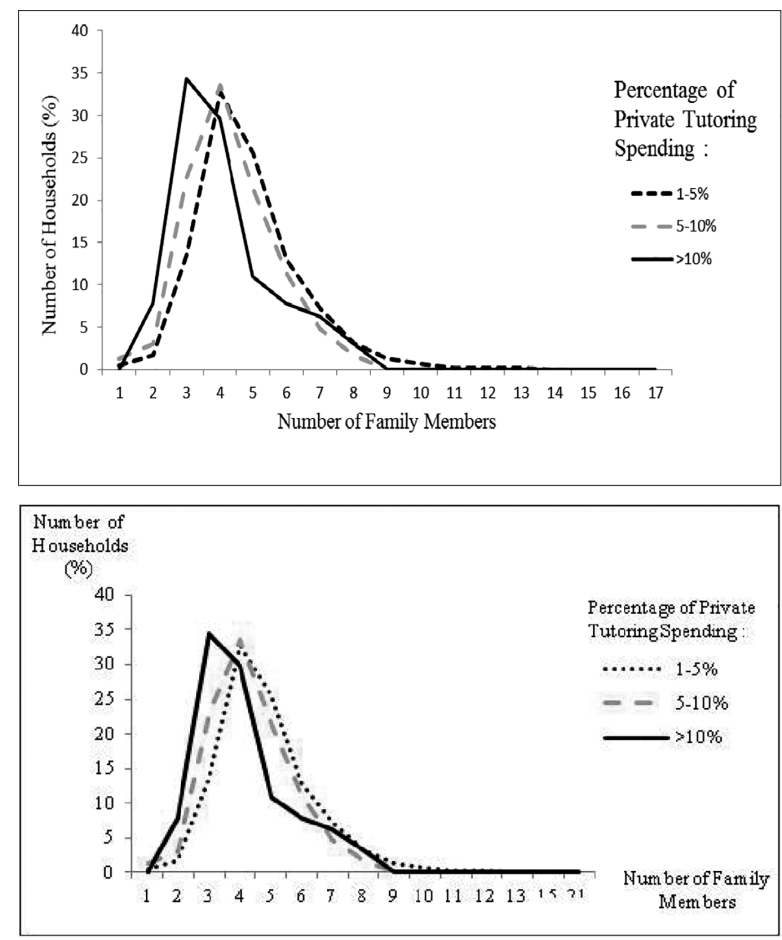

Figure 3. Number of family members and percentage of private tutoring spending by household. 


\section{THE ESTIMATION OF HOUSEHOLD CHARACTERISTICS EFFECT}

Table 2 shows that our estimation results are fairly robust for alternative specifications and the main model for analysis in this study is Model 5. Table 3 shows that the total household expenditure positively and significantly affects household expenditure on private tutoring. This happens due to the increasing amount of budget-share allocated for educational spending, including private tutoring expenditure. The simultaneous increase of household demand for private tutoring and increase of household income indicates that private tutoring has functioned as normal goods. Similar cases are also found in several studies conducted by Bray and Kwok (2003), Jelani et al. (2014), Tansel and Bircan (2006), Dang (2007); Bray et al. (2014), Dang and Rogers (2008), and Kim and Lee (2010).

Table 2. Estimation result with Tobit model.

\begin{tabular}{|c|c|c|c|c|c|}
\hline Independent variable & Model 1 & Model 2 & Model 3 & Model 4 & Model 5 \\
\hline \multirow{2}{*}{$\begin{array}{l}\text { Ln. Total Household } \\
\text { Expenditure }\end{array}$} & $4.022 * * *$ & $3.841 * * *$ & $3.595^{* * *}$ & $3.088 * * *$ & $2.835^{* * *}$ \\
\hline & $(0.387)$ & $(0.661)$ & $(0.688)$ & $(0.718)$ & $(0.749)$ \\
\hline Ln. Formal Education Cost & $\begin{array}{l}-0.951^{* * *} \\
(0.161)\end{array}$ & $\begin{array}{l}-0.594^{* * * *} \\
(0.168)\end{array}$ & $\begin{array}{l}-0.588^{* * * *} \\
(0.169)\end{array}$ & $\begin{array}{l}-0.619 * * * \\
(0.169)\end{array}$ & $\begin{array}{l}-0.624^{* * *} \\
(0.170)\end{array}$ \\
\hline \multirow[t]{2}{*}{$\begin{array}{l}\text { Ln. Formal Education's Cost } \\
\text { Square }\end{array}$} & $0.186^{* * *}$ & $0.142 * * *$ & $0.141 * * *$ & $0.143^{* * *}$ & $0.144^{* * *}$ \\
\hline & $(0.012)$ & $(0.013)$ & $(0.013)$ & $(0.013)$ & $(0.013)$ \\
\hline \multirow[t]{2}{*}{$\begin{array}{l}\text { Number of Tutoring Agency } \\
\text { (Bimbel) }\end{array}$} & $0.142 * * *$ & $0.133^{* * *}$ & $0.132 * * *$ & $0.0989 * * *$ & $0.0979 * * *$ \\
\hline & $(0.011)$ & $(0.011)$ & $(0.011)$ & $(0.011)$ & $(0.011)$ \\
\hline Middle School Education Level & & $\begin{array}{l}4.367 * * * \\
(0.329)\end{array}$ & $\begin{array}{l}4.198 * * * \\
(0.333)\end{array}$ & $\begin{array}{l}4.339 * * * \\
(0.328)\end{array}$ & $\begin{array}{l}4.168 * * * \\
(0.332)\end{array}$ \\
\hline High School Education Level & & $\begin{array}{l}5.200 * * * \\
(0.354)\end{array}$ & $\begin{array}{l}4.996 * * * \\
(0.359)\end{array}$ & $\begin{array}{l}5.197 * * * \\
(0.354)\end{array}$ & $\begin{array}{l}4.969 * * * \\
(0.359)\end{array}$ \\
\hline Father's Years of Schooling & & $\begin{array}{l}0.101^{* *} \\
(0.038)\end{array}$ & $\begin{array}{l}0.118^{* *} \\
(0.039)\end{array}$ & $\begin{array}{l}0.0793^{*} \\
(0.037)\end{array}$ & $\begin{array}{l}0.0912^{*} \\
(0.038)\end{array}$ \\
\hline Mother's Years of Schooling & & $\begin{array}{l}0.0854 * \\
(0.036)\end{array}$ & $\begin{array}{l}0.0883^{*} \\
(0.038)\end{array}$ & $\begin{array}{l}0.0693 \\
(0.036)\end{array}$ & $\begin{array}{l}0.0728 * \\
(0.037)\end{array}$ \\
\hline Number of Family Members & & $\begin{array}{l}-1.199 * * * \\
(0.107)\end{array}$ & $\begin{array}{l}-1.246^{* * *} \\
(0.107)\end{array}$ & $\begin{array}{l}-1.104^{* * *} \\
(0.109)\end{array}$ & $\begin{array}{l}-1.154 * * * \\
(0.110)\end{array}$ \\
\hline Female & & & $\begin{array}{l}0.835^{* *} \\
(0.272)\end{array}$ & $\begin{array}{l}0.783^{* *} \\
(0.271)\end{array}$ & $\begin{array}{l}0.790^{* *} \\
(0.270)\end{array}$ \\
\hline Household Head's Age & & & $\begin{array}{l}0.177^{*} \\
(0.082)\end{array}$ & & $\begin{array}{l}0.203^{*} \\
(0.082)\end{array}$ \\
\hline Household Head's Age Square & & & $\begin{array}{l}-0.00132 \\
(0.001)\end{array}$ & & $\begin{array}{l}-0.00161 \\
(0.001)\end{array}$ \\
\hline Urban & & & & $\begin{array}{l}4.335^{* * *} \\
(0.349)\end{array}$ & $\begin{array}{l}4.377 * * * \\
(0.352)\end{array}$ \\
\hline Scholarship & & & & $\begin{array}{l}2.275^{* * *} \\
(0.431)\end{array}$ & $\begin{array}{l}2.246^{* * *} \\
(0.431)\end{array}$ \\
\hline Public Schools & & & & $\begin{array}{l}1.979^{* * *} \\
(0.399)\end{array}$ & $\begin{array}{l}1.983^{* * *} \\
(0.399)\end{array}$ \\
\hline _cons & $\begin{array}{l}-101.9^{* * *} \\
(6.258)\end{array}$ & $\begin{array}{l}-95.15^{* * *} \\
(10.073)\end{array}$ & $\begin{array}{l}-96.58 * * * \\
(10.302)\end{array}$ & $\begin{array}{l}-87.17 * * * \\
(10.927)\end{array}$ & $\begin{array}{l}-88.59 * * * \\
(11.173)\end{array}$ \\
\hline sigma_cons & $\begin{array}{l}18.65^{* * * *} \\
(0.090)\end{array}$ & $\begin{array}{l}18.32 * * * \\
(0.089)\end{array}$ & $\begin{array}{l}18.31^{* * *} \\
(0.089)\end{array}$ & $\begin{array}{l}18.14^{* * *} \\
(0.087)\end{array}$ & $\begin{array}{l}18.12 * * * \\
(0.087)\end{array}$ \\
\hline $\mathrm{N}$ & 66,234 & 66,234 & 66,234 & 66,234 & 66,234 \\
\hline pseudo R-sq & 0.0345 & 0.0422 & 0.0427 & 0.0472 & 0.0475 \\
\hline
\end{tabular}

Robust standard errors in parentheses, *significant at 10\%, **significant at 5\%, $* * *$ significant at $1 \%$. 
The education level of fathers and mothers positively and significantly affects household expenditure for private tutoring. The effect of fathers' education level is stronger than mothers' education level. The results are different from the study conducted by Tansel and Bircan (2006), Dang (2007), Bray et al. (2014), and Jelani et al. (2014). This happens due to the fact that on average, fathers' education level is higher than mothers' education level. The higher one's education level, it is assumed that the preference and expectation on returns for children's education in the future will also be higher. A head of the household with higher education level usually gets a job with a higher salary. Therefore, this household group will tend to spend more for private tutoring (Dang \& Rogers, 2008).

The number of family members negatively and significantly affects household expenditure for private tutoring. A larger number of family members means more household spending allocation that needs to be fulfilled under limited available household income. Thus, it will cause a decrease in household expenditure for private tutoring. Similar cases are found in some studies conducted by Tansel and Bircan (2006), and Kim and Lee (2010).

The higher number of tutoring agencies available in an area increases household demand for private tutoring, because it provides more price options for households. Meanwhile, tutoring agencies become more accessible with lower transportation cost so that the tutoring agencies are relatively cheaper than those in areas with a lower number of tutoring agencies. Higher cost of formal education causes a decrease in household expenditure for private tutoring with an increasing reduction rate, along with expensive formal education costs. This occurs due to the fact that there are gradual reductions of part of the income that can be allocated for private tutoring expenditure. The relationship between formal education costs and household expenditure for private tutoring reflects cross-price elasticity level. The coefficient of estimation result (Table 3) shows that formal education and private tutoring cannot replace each other. Instead, both factors are complementary to each other (Dang \& Rogers, 2008).

The age of the head of a household positively and significantly affects household expenditure for private tutoring. This is because the advancement in the age of the head of a household usually goes along with the betterment of the household's economic condition. Moreover, the older the head of the household, the experience and knowledge of the importance of investment for children's education is also increasing. This affects the increase in spending for private tutoring with the reduction on the increasing level. Increasing effects of the household head's age to household spending on private tutoring follows the pattern of life cycle of the household head's expenditure (Tansel \& Bircan, 2006). Table 3 shows that the increase in spending on private tutoring follows the age of the household head and reaches the optimum point at the age of 63 , which is near the optimum level of the age of productive labour in Indonesia, which is 64 years.

Households living in urban areas spend a larger share of their income for private tutoring, as many as $63.4 \%$ larger than households living in rural areas. This happens because there are more private tutoring agencies available in urban areas, so that families living in urban areas may get easier access to that particular service compared to families living in rural areas (Tansel \& Bircan, 2006).

Demand for private tutoring is increasing along with the higher education level of children, where at high school level the necessity for private tutoring is considered the highest compared to the levels below. This is due to the high competition for admission to the best universities. Children and parents assume that getting admitted to the best universities can improve children's competitiveness in the labour market. Children who get scholarships will have more opportunities to participate in private tutoring. This is due to the fact that by getting scholarships, they have the opportunity to pay for private tutoring services. Moreover, children who get scholarships must maintain their academic achievement so that they need to get private tutoring.

Households spend $11.44 \%$ more for female children's private tutoring. It is estimated that daughters tend to have more learning motivation and a higher level of anxiety about their academic achievement compared to sons, so that parents feel the need to send their daughters for private tutoring. This assumption is contradictory to the studies conducted by Bray et al. (2014), Jelani et al. (2014), and Dang (2007), who found that there is no difference in demand 
for private tutoring among females and males. Demand for private tutoring increases by about $28.7 \%$ for children who attend public schools. This indicates that the quality of private schools is better than public schools. Commonly, private schools provide a better and more complete education package than public schools. Therefore, some households tend to choose to send their children to private schools, instead of supplying their needs to get better education from private tutoring (Bray et al., 2014).

\section{CONCLUSION}

A more settled condition of a household will motivate the household's spending on children's private tutoring. This is signified by the higher education level of the parents, total household expenditure, age of the head of the household and the number of family members. The high education level of parents correlates to the types of occupations in which the salary level is also higher. It leads to a high total of household income, which leads to more resources that can be allocated such as for private tutoring expenditure. The spending on private tutoring follows the life cycle expenditure pattern of the head of the household.

Besides the household characteristics explained previously, household expenditure level for private tutoring is also significantly affected by children's education level and household domicile, whether a household lives in an urban or rural area. The high level of children's education will motivate the parents in spending more for private tutoring. This indicates that a household's high necessity for education is in line with the high level of education being attended by the children. Meanwhile, households living in urban areas tend to spend more of their income for private tutoring than households living in rural areas. Households living in urban areas on average have a higher education level and higher income compared to households living in rural areas. These are the factors that support the high demand for private tutoring in urban areas.

\section{REFERENCES}

Amemiya, T. (1974). Multivariate regression and simultaneous equation models when the dependent variables are truncated normal. Econometrica, 42(6), 999-1012. doi:10.2307/1914214.

Becker, G.S. \& Lewis, H.G. (1973). On the interaction between the quantity and quality of children. The Journal of Political Economy, 81(2), S297-A288.

Bray, M. \& Kwok, P. (2003). Demand for private supplementary tutoring: Conceptual considerations, and socio-economic patterns in Hong Kong. Economics of Education Review, 22(6), 611-620. doi:10.1016/S0272-7757(03)00032-3.

Bray, M., Zhan, S., Lykins, C., Wang, D. \& Kwo, O. (2014). Differentiated demand for private supplementary tutoring: Patterns and implications in Hong Kong secondary education. Economics of Education Review, 38, 24-37. doi:10.1016/j.econedurev.2013.10.002.

Dang, H.A. (2007). The determinants and impact of private tutoring classes in Vietnam. Economics of Education Review, 26(6), 683-698. doi:10.1016/j.econedurev.2007.10.003.

Dang, H.A. \& Rogers, F.H. (2008). The growing phenomenon of private tutoring: Does it deepen human capital, widen inequalities, or waste resources? World Bank Research Observer, 23(2), 161-200. doi: 10.1093/wbro/lkn004.

Dang, H.A.H. \& Rogers, F.H. (2016). The decision to invest in child quality over quantity: Household size and household investment in education in Vietnam. World Bank Economic Review, 30(1), 104 142. doi:10.1093/wber/lhv048Davies, S. (2004). School choice by default? Understanding the demand for private tutoring in Canada. American Journal of Education, 110(3), 233-255.

Jelani, J., Tan, A.K.G. \& Mohd-Zaharim, N. (2014). Demand for extracurricular activities amongst primary school students: Exploratory evidence from survey data in Penang (Malaysia). The Asia-Pacific Education Researcher, 24(1), 125-135. doi:10.1007/s40299-013-0165-y.

Kim, S. \& Lee, J.H. (2010). Private tutoring and demand for education in South Korea. Economic Development and Cultural Change, 58(2), 259-296. doi:10.1086/648186.

Kristiansen, S. \& Pratikno, P. (2006). Decentralising education in Indonesia. International Journal of Educational Development, 26(5), 513-531. doi:10.1016/j.ijedudev.2005.12.003. 
Liviatan, N. (1961). Errors in variables and Engel curve analysis. Econometrica, 29(3), 336.

Mori, I. \& Baker, D. (2010). The origin of universal shadow education: What the supplemental education phenomenon tells us about the postmodern institution of education. Asia Pacific Education Review, 11(1), 36-48. doi:10.1007/s12564-009-9057-5.

Novita, M. (2008). Pengaruh karakteristik rumah tangga dalam fungsi permintaan Pendidikan. Magister's thesis, Program Pasca Sarjana Ilmu Ekonomi Fakultas Ekonomi dan Bisnis, Universitas Indonesia.

Psacharopoulos, G. \& Papakonstantinou, G. (2005). The real university cost in a 'free' higher education country. Economics of Education Review, 24(1), 103-108.

Smith, R.J. \& Blundell, R.W. (1986). An exogeneity test for a simultaneous equation Tobit model with an application to labor supply. Econometrica, 54(3), 679-685.

Takayama, K., Waldow, F. \& Sung, Y.K. (2013). Finland has it all? Examining the media accentuation of 'Finnish education' in Australia, Germany and South Korea. Research in Comparative and International Education, 8(3).

Tansel, A. \& Bircan, F. (2006). Demand for education in Turkey: A Tobit analysis of private tutoring expenditures. Economics of Education Review, 25(3), 303-313. 